\title{
Clinical manifestations and diagnosis of acute myeloid leukemia in a patient with a medical history of pulmonary tuberculosis (a case report)
}

\author{
0. M. Raznatovska ${ }^{\star 1, A-D, F}$, O. S. Shalmin ${ }^{1, A, C, E}$, S. B. Noreiko ${ }^{2}{ }^{2, A, C, E}$ \\ ${ }^{1}$ Zaporizhzhia State Medical University, Ukraine, ${ }^{2}$ Bogomolets national medical university, Kyiv, Ukraine
}

A - research concept and design; B - collection and/or assembly of data; C - data analysis and interpretation; D - writing the article; $\mathrm{E}$ - critical revision of the article; $\mathrm{F}$ - final approval of the article

Key words: pulmonary tuberculosis, acute myeloid leukemia.

Zaporozhye

medical journal

2020; 22 (5), 732-736

*E-mail:

raxnatovskaya@gmail. com
The aim is to familiarize practitioners with the initial clinical manifestations of acute myeloid leukemia and its diagnosis in a patient with a past medical history of pulmonary tuberculosis.

Materials and methods. The article presents a clinical case of acute myeloid leukemia clinical manifestations based on our own clinical experience and its diagnosis in the patient with previous pulmonary tuberculosis. The patient was followed-up and diagnosed with acute myeloid leukemia in the Municipal Institution "Zaporizhzhia Regional Tuberculosis Clinical Dispensary".

Results. The patient presented in this study was diagnosed with pulmonary tuberculosis and received antimycobacterial treatment including isoniazid and rifampicin, which may have initially contributed to the hematopoietic mechanisms impairment. Perhaps the stressful situation triggered the development of acute myeloid leukemia due to underlying impaired mechanisms of hematopoiesis that had occurred. In this case, the initial clinical manifestations were weakness, loss of appetite and weight loss. A clinical blood analysis with leukogram and the bone marrow biopsy with aspirate examination became priority methods in diagnosing acute myeloid leukemia.

The clinical case presented primarily demonstrates patient's irresponsibility for their own health, who having symptoms such as weakness, loss of appetite, and weight loss for 5 months as well as past medical history of tuberculosis, did not seek medical advice timely.

Conclusions. In a patient with a past medical history of pulmonary tuberculosis, priority task is to confirm or rule out reactivation tuberculosis. The initial clinical manifestations of acute myeloid leukemia are: unprovoked weakness for several months; increasing exertional dyspnea; anemia, leukopenia, neutropenia, ESR acceleration.

The primary methods to diagnose acute myeloid leukemia are: clinical blood test with leukogram, biochemical blood tests to determine the levels of erythropoietin, ferritin and vitamin B12; bone marrow biopsy with aspirate examination (myelogram); cytochemical examination of bone marrow (myeloperoxidase); bone marrow immunophenotyping (expression of myeloid-associated antigens).

Ключові слова: туберкульоз мегень, гостра мієлоїдна лейкемія.

Запорізький медичний журнал.

2020. T. 22, № 5(122)

C. $732-736$

\section{Киінічні прояви та діагностика гострої мієлоїдної мейкемії в пацієнта з перенесеним раніше туберкульозом легень (киінічний випадок)}

\section{О. М. Разнатовська, О. С. Шальмін, С. Б. Норейко}

Мета роботи - ознайомлення фахівців-практиків із початковими клінічними проявами розвитку гострої мієлоїдної лейкемії та її діагностикою в пацієнта, який раніше мав туберкульоз легень.

Матеріали та методи. Наведено клінічний випадок власного спостереження розвитку клінічних проявів гострої мієлоїдної лейкемії та її діагностики в пацієнта, який раніше мав туберкульоз легень. Спостереження за пацієнтом і діагностику гострої мієлоїдної лейкемії здійснили в КУ «Запорізький обласний протитуберкульозний клінічний диспансер».

Результати. У пацієнта, результати обстеження та лікування якого наведені в роботі, в анамнезі був туберкульоз легень, хворий отримав антимікобактерільне лікування. Серед протитуберкульозних препаратів - ізоніазид і рифампіцин, що, можливо, спричинили порушення механізмів гемопоезу. Імовірно, стресова ситуація стала поштовхом для розвитку гострої мієлоїдної лейкемії на тлі вже порушених механізмів гемопоезу. У випадку, який описали, початковими клінічними проявами були слабкість, зниження апетиту, втрата ваги. Першочергові методи діагностики гострої мієлоїдної лейкемії: загальний аналіз крові з лейкоцитарною фрормулою, стернальна пункція з дослідженням пунктату кісткового мозку.

Клінічний випадок, що наведений, демонструє передусім безвідповідальне ставлення до здоров'я самого пацієнта, який, маючи протягом 5 місяців такі симптоми, як слабкість, зниження апетиту, втрата ваги тіла та туберкульоз в анамнезі, своєчасно не звернувся до лікаря на дообстеження.

Висновки. У пацієнта, який раніше мав туберкульоз легень, насамперед необхідно підтвердити чи виключити реактивацію туберкульозного процесу. Початкові клінічні прояви гострої мієлоїдної лейкемії: немотивована слабкість протягом кількох місяців, задуха, що посилюється під час фізичного навантаження, анемія, лейкопенія, нейтропенія, прискорена ШОЕ

Першочерговими методами діагностики гострої мієлоїдної лейкемії є загальний аналіз крові з лейкоцитарною формулою; біохімічний аналіз крові з визначенням рівнів еритропоетину, феритину та вітаміну В12; стернальна пункція з дослідженням пунктату кісткового мозку (мієлограма); цитохімічне дослідження кісткового мозку (мієлопероксидаза); імунофенотипування кісткового мозку (експресія мієлоїдних антигенів). 


\section{Клинические проявления и диагностика острой миелоидной мейкемии у пациента с перенесенным ранее туберкулезом легких (клинический случай)}

\section{Е. Н. Разнатовская, А. С. Шальмин, С. Б. Норейко}

Цель работы - ознакомление специалистов-практиков с начальными клиническими проявлениями развития острой миелоидной лейкемии и ее диагностикой у пациента, который в прошлом перенес туберкулез легких.

Материалы и методы. Описан клинический случай собственного наблюдения развития клинических проявлений острой миелоидной лейкемии и ее диагностики у пациента, который в прошлом перенес туберкулез легких. Наблюдение за пациентом и диагностика острой миелоидной лейкемии проведены в КУ «Запорожский областной противотуберкулезный клинический диспансер».

Результаты. У пациента, результаты обследования и лечения которого описаны в работе, в анамнезе был туберкулез, больной получил антимикобактерильное лечение. Среди противотуберкулезных препаратов - изониазид и рифампицин, которые, возможно, способствовали нарушению механизмов гемопоэза. Вероятно, именно стрессовая ситуация стала толчком для развития острой миелоидной лейкемии на фоне уже нарушенных механизмов гемопоэза. В представленном случае начальными клиническими проявлениями стали слабость, снижение аппетита и потеря веса. Первоочередные методы диагностики острой миелоидной лейкемии: общий анализ крови с лейкоцитарной формулой, стернальная пункция с исследованием пунктата костного мозга.

Представленный клинический случай демонстрирует прежде всего безответственное отношение к здоровью самого пациента, который, имея в течение 5 месяцев такие симптомы, как слабость, снижение аппетита, потеря веса и туберкулез в анамнезе, своевременно не обратился к врачу на дообследование.

Выводы. У пациента, который в прошлом перенес туберкулез легких, в первую очередь необходимо подтвердить или исключить реактивацию туберкулезного процесса. Начальные клинические проявления острой миелоидной лейкемии: немотивированная слабость в течение нескольких месяцев, нарастающая одышка при физической нагрузке; анемия, лейкопения, нейтропения, ускоренная СОЭ. Первоочередные методы диагностики острой миелоидной лейкемии: общий анализ крови с лейкоцитарной формулой; биохимический анализ крови с определением уровней эритропоэтина, ферритина и витамина В12; стернальная пункция с исследованием пунктата костного мозга (миелограмма) цитохимические исследования костного мозга (миелопероксидаза), иммунофенотипирование костного мозга (экспрессия миелоидных антигенов).

Tuberculosis is a chronic infectious disease in which changes in the immune system are determined by both a result of the disease itself and adverse effects of antimycobacterial therapy [1].

Acute myeloid leukemia is a malignant heterogeneous tumor disease of the blood system characterized by a clonal expansion of myeloblasts in the bone marrow, peripheral blood and other organs and tissues [2].

Myeloid leukemia, both acute and chronic, is a risk factor for developing an opportunistic disease - active tuberculosis $[3,4]$. A combined course of both diseases in active phase raises a number of treatment challenges. Above all, it is therapy-related toxicities resulting in poor adherence to treatment among patients. Besides, active tuberculosis increases mortality rate in patients with myeloid leukemia.

It is now known that specific tuberculous intoxication, decrease in systemic and antituberculosis immune response [5], antituberculosis drug treatment [6] contribute to abnormalities in the mechanisms of hematopoiesis and the development of leukemia in patients with pulmonary tuberculosis. Thus, side effects of some antimycobacterial drugs (isoniazid, rifampicin) manifest themselves mainly in all the contrary way, as leukopenia and agranulocytosis [1].

Thomas M. and AlGherbawe M. [7] reported a case of acute myeloid leukemia in a man who was started on treatment that included isoniazid, rifampicin, pyrazinamide and ethambutol for active pulmonary tuberculosis. The main symptoms of diagnostic suspicion of acute myeloid leukemia in the patient were severe neutropenia with monocytosis accompanied by severe intoxication, the manifestations of which were identical for both diseases. Bone marrow biopsy confirmed the diagnosis of acute myeloid leukemia. Jain A. et al. [3] also emphasized the significance of febrile neutropenia as a diagnostic criterion for acute myeloid leukemia in patients with active tuberculosis.

The literature describes cases of active tuberculosis presenting concomitantly with acute myeloid leukemia. However, there are no data on the development of acute myeloid leukemia after suffering pulmonary tuberculosis.

\section{Aim}

To familiarize practitioners with the initial clinical manifestations of acute myeloid leukemia and its diagnosis in a patient with a past medical history of pulmonary tuberculosis.

\section{Materials and methods}

The article presents a clinical case of acute myeloid leukemia clinical manifestations based on our own clinical experience and its diagnosis in the patient with previous pulmonary tuberculosis. The patient was followed-up and diagnosed with acute myeloid leukemia in the Municipal Institution "Zaporizhzhia Regional Tuberculosis Clinical Dispensary" (ZRTBCD).

\section{Clinical case presentation}

A 42-year-old male received treatment for disseminated pulmonary tuberculosis 4 years ago. The treatment regimen included first-line anti-tuberculosis drugs: isoniazid (180 doses), rifampicin (180 doses), ethambutol (60 doses), pyrazinamide (60 doses), and streptomycin (60 doses) since tuberculosis was drug-sensitive. He successfully completed the treatment with residual changes after tuberculosis.
Киючевые слова: туберкулез мегких, острый миелоиАный мейкоз.

Запорожский медицинский журнал. 2020. T. 22, № 5(122). C. $732-736$ 


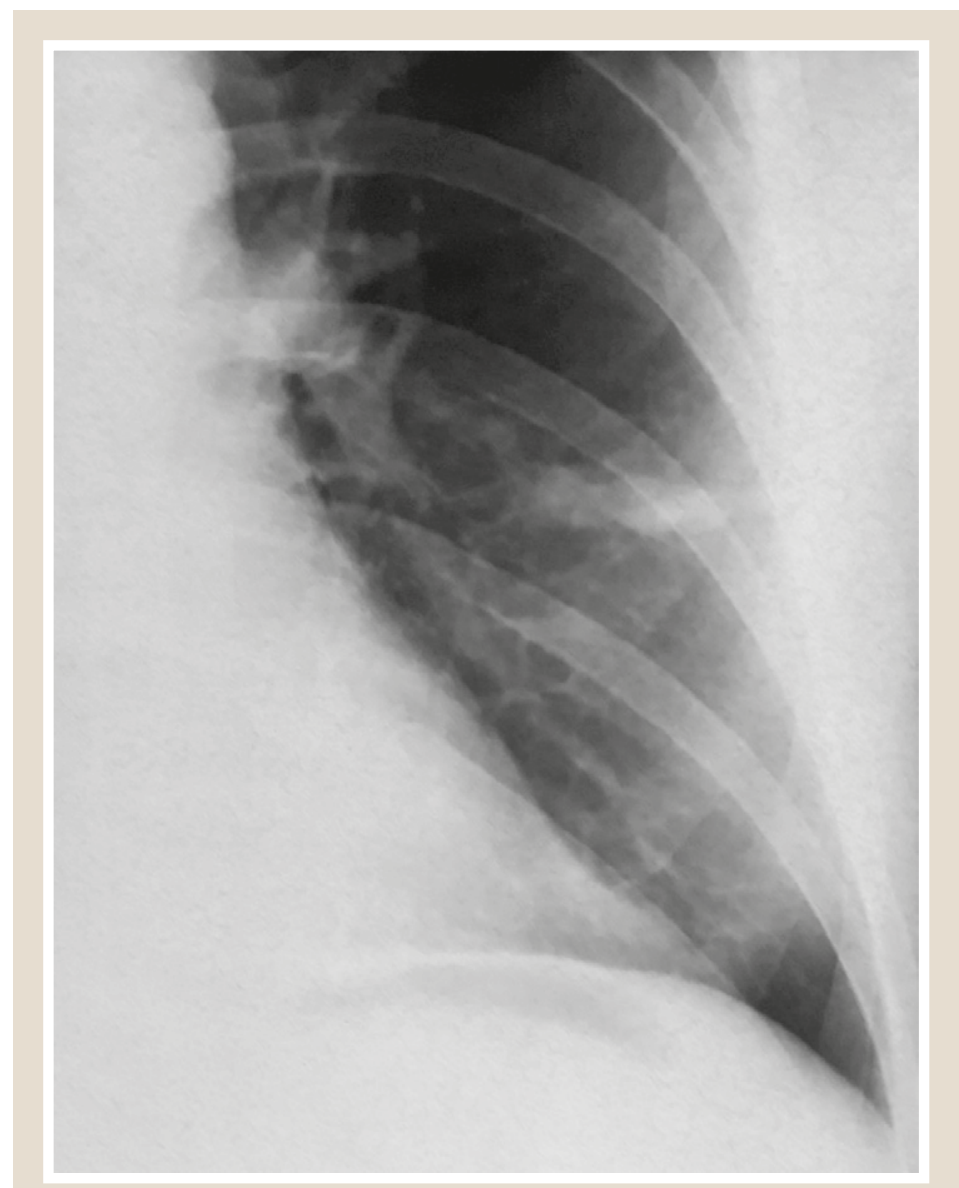

Fig. 1. Chest radiograph: an area of reduced pneumatization with a homogeneous structure and insufficiently clear contours in the upper lobe of the left lung at the base of the 4th segment.

A progressive deterioration of his general condition was evident 5 months before the present disease as unprovoked weakness, loss of appetite, and weight loss. However, he paid no attention associating it with a stressful situation matrimonial difficulties.

One week prior to hospital admission, he developed mild exertional dyspnea and skin pallor in addition to the above-mentioned changes in his general condition.

Taking into account the past medical history of pulmonary tuberculosis, a chest X-ray was performed (Fig. 1) revealing abnormalities.

A fibrobronchoscopy (FBS) was performed showing left-sided mucosal infiltration of the B6 without stenosis, metatuberculous changes of the bronchial mucosa due to intrathoracic lymph nodes involvement.

Mycobacterium tuberculosis (MBT) was not detected by bacterioscopic or molecular genetic methods in a bronchial aspirate.

A tumor marker test (serum carcino-embryonic antigen) was negative.

However, taking into account the anamnesis, radiological and FBS findings, the patient was admitted to the ZRT$\mathrm{BCD}$ in order to rule out or confirm tuberculosis recurrence.

An admission clinical blood analysis (CBA) revealed the following changes: hemoglobin $(\mathrm{Hb})-45 \mathrm{~g} / \mathrm{l}$ (normal range $130-160 \mathrm{~g} / \mathrm{l}$ ), erythrocytes $-2.03 \times 10^{12} / \mathrm{l}$ (normal range $\left.4.0-5.0 \times 10^{12} / \mathrm{l}\right)$, leukocytes $-2.6 \times 10^{9} / \mathrm{l}$ (normal range 4.0-9.0 × 10\%/l), platelets - $192 \mathrm{~g} / \mathrm{l}$, erythrocyte sedimentation rate $(E S R)-56 \mathrm{~mm} / \mathrm{h}$ (normal range $1-10 \mathrm{~mm} / \mathrm{h}$ ), banded (b) $-6 \%$, segmented (s) $-8 \%$, lymphocytes (I) $78 \%$, monocytes $(\mathrm{m})-8 \%$.

Blood transfusion therapy was initiated concurrently with antimycobacterial therapy and detoxification given the result of CBA.

Enlarged peripheral lymph nodes were not present. However, an abdominal ultrasound revealed right-sided mediastinal and retroperitoneal lymphadenopathy.

Fibrogastroduodenoscopy was performed showing no pathological changes.

Electrocardiogram (ECG) revealed normal voltage and sinus rhythm with a heart rate $(\mathrm{HR})$ at $84 \mathrm{bpm}$.

Plasma D-dimer level was $1163 \mathrm{ng} / \mathrm{ml}$ (normal range $0-500 \mathrm{ng} / \mathrm{ml}$ ).

After 5 days of intensive therapy, the CBA showed the following changes: hemoglobin $(\mathrm{Hb})-86.5 \mathrm{~g} / \mathrm{l}$, erythrocytes $-2.86 \times 10^{12} /$, leukocytes - $1.7 \times 10^{9} /$, platelets $198 \mathrm{~g} / \mathrm{l}, \mathrm{ESR}-63 \mathrm{~mm} / \mathrm{h}$, metamyelocytes $-1 \%, \mathrm{~b}-6 \%$, $s-20 \%, l-73 \%, m-3 \%$, anisocytosis, poikilocytosis. Liver function tests were within normal ranges. A serum HIV antibody test was negative.

The patient was consulted by a professor oncologist who concluded an absence of radiological features of lung cancer. Leukemic infiltration and recurrence of the tuberculous process were considered to be the most likely causes of changes in the lungs. Hence, it was recommended that a bone marrow biopsy and a hematologist consultation be done to rule out acute leukemia.

The next day, during a consultation with a hematologist, a sternal bone marrow puncture was performed and further biochemical blood testing was scheduled.

Thus, the blood biochemical analysis revealed: erythropoietin $-2041.0 \mathrm{mlU} / \mathrm{ml}$ (normal range $4.3-29.0 \mathrm{mlU} / \mathrm{ml}$ ), ferritin - 774.6 ng/l (normal range 30.0-400.0 ng/l), vitamin B12 - $1302 \mathrm{pmol} / /$ (normal range 145.0-569.0 pmol//), folic acid $-5.84 \mathrm{nmol} / \mathrm{l}$ (normal range 10.4-42.4 nmol/l), iron $17.4 \mu \mathrm{mol} / \mathrm{l}$ (normal range 12.5-32.2 $\mu \mathrm{mol} / \mathrm{l}$ )

Acytochemical examination of the bone marrow for myeloperoxidase revealed a positive result of the granulocytic lineage - positive in $12 \%$ of blast cells.

The result of bone marrow aspirate (myelogram): the bone marrow aspirate was hypercellular due to blast cell infiltration. A cellular composition was polymorphic and represented by all hematopoietic lineages. The granulocyte lineage dysplasia (granulation of cytoplasm) reflected differentiation block. Erythropoiesis was characterized by signs of dyserythropoiesis (megaloblastoid nuclei). Single megakaryocytes with a moderate degree of platelet release were observed. There were medium-sized blast cells, granular and with fine azurophilic granules. Dysgranulocytopoesis was found in $98 \%$ of granulocytes, dyserythropoiesis - in $31 \%$ of erythrokaryocytes. The findings were that this morphological picture of bone marrow aspirate most likely corresponded to acute myeloid leukemia with changes related to myelodysplasia. Immunophenotyping and molecular genetic analysis were recommended to assess clonality of the process.

Recurrent tuberculosis was ruled out. The patient was transferred to the hematology department for further examination and treatment of acute myeloid leukemia. 
Immunophenotyping of hemoblastoses in a bone marrow aspirate smear (CD3/CD16 + CD56/CD45/CD19, CD7, CD14PE, AntiHLA-DR/CD34, CD117, CD33) was performed in the hematology department. Acute leukemia panel. Light parameters FSC/SSC scatter and CD45 expression and granularity (CD45/SSC) revealed the following distribution of immunophenotypically different bone marrow cells populations:

- R1 Gate (Fig. 2) - mature lymphocytes isolated as low granularity cells expressing CD45 (IFI - 786.97 r. u.) amounting to $7.39 \%$. CD16/CD56 - $12.31 \%$, CD19 $18.67 \%$, CD3 - 63.3 \%. Lymphocytes were represented by T-, B- and NK-cells with a predominance of T-lymphocytes.

- R3 Gate (Fig. 3) - cells of the granulocytic lineage, isolated as cells of high granularity, amounting to $45.61 \%$ : CD16/CD56 - 63.73 \%, CD19 - 1.82 \%, CD3 - $7.81 \%$, CD33+/HLADR - $-11.48 \%$, CD33 + /HLADR + -87.58 \%, CD33-/HLADR + - $0.25 \%$, CD $14-21.99 \%$, CD7 $-36.19 \%$, CD $117-27.53 \%$, CD34-9.15\%, CD10-3.21\%, CD5$4.55 \%$.

Monocytes by expression of CD14 accounted for $10.08 \%$ of all nucleated white cells of the bone marrow aspirate. Granulocytes mainly comprised young forms of CD33 +/HLADR+. A feature of granulocytes in the patient was hypogranularity (low SSC) indicating dysgranulocytopoiesis.

- R2 Gate (Fig. 3) - blast cells isolated as medium sized cells of low granularity (according to FSC/SSC characteristics) with lower level of CD45 (IFI - 235.57 r. u.), accounted for $30.3 \%$ of all white cells of the bone marrow aspirate: CD16/CD56 - $69.08 \%$, CD19 - $1.75 \%$, CD3 - $7.43 \%$, CD33+/HLADR - - $1.43 \%$, CD33+/HLADR+ -83.8\%, CD33-/ HLADR + -3.62 \%, CD14- $4.77 \%$, CD7 - 58.9\%, CD 117 $82.27 \%$, CD34 - $65.7 \%$, CD10 - 1.42 \%, CD5 - $10.04 \%$.

Blast cells were both B-lineage (CD19, CD10) and T-lineage (CD3, CD5) negative as well as for monocytic differentiation marker (CD14). Blasts mostly showed a homogenous expression of lineage myeloid marker CD33 (high) and HLADR (high). To determine the stage of myeloid maturation, the expression of CD34 and CD117 as markers of progenitor cells was analyzed. Blast cells mainly homogeneously expressed CD117 (high) and CD34 (low) and were characterized by aberrant expression of lymphoid markers CD7 and CD16/56.

It was concluded that the presented changes corresponded to intermediate degree of leukemia cell differentiation.

\section{Discussion}

The patient presented in this study was diagnosed with pulmonary tuberculosis and received antimycobacterial treatment including isoniazid and rifampicin, which may have initially contributed to the hematopoietic mechanisms impairment. Perhaps the stressful situation (he took matrimonial difficulties hard) triggered the development of acute myeloid leukemia due to underlying impaired mechanisms of hematopoiesis that had occurred.

In contrast to the clinical manifestations of acute myeloid leukemia, which develops in active pulmonary tuberculosis (severe intoxication syndrome) [7], in this case, the initial clinical manifestations were weakness, loss of appetite and weight loss.

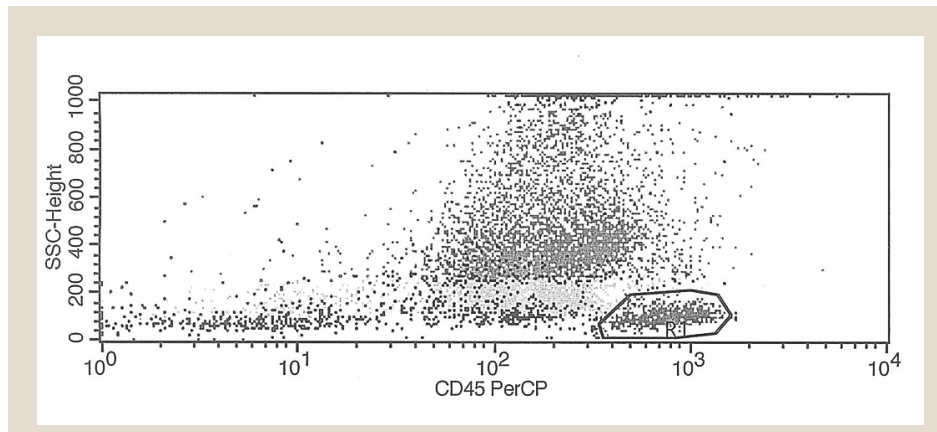

Fig. 2. R1 Gate.

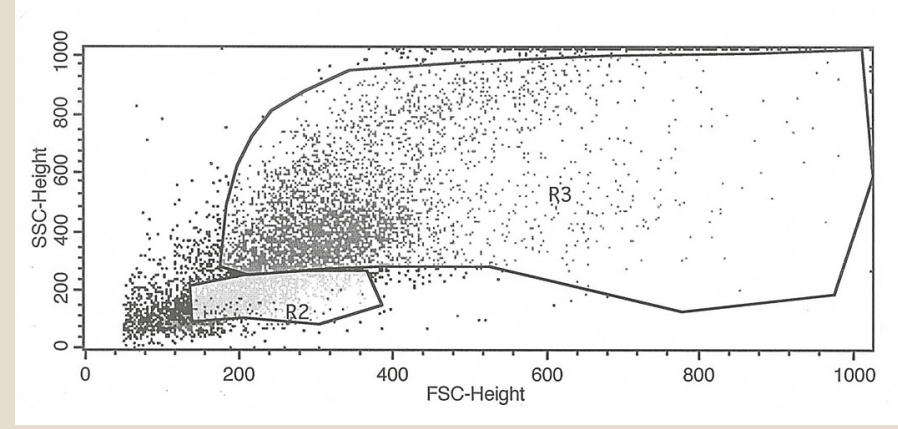

Fig. 3. R2 Gate, R3 Gate.

CBA with leukogram and the bone marrow biopsy with aspirate examination, which are emphasized by other authors [3-5,7], became priority methods in diagnosing acute myeloid leukemia.

The clinical case presented primarily demonstrates patient's irresponsibility for their own health, who having symptoms such as weakness, loss of appetite, and weight loss for 5 months as well as past medical history of tuberculosis, did not seek medical advice timely.

\section{Conclusions}

In a patient with a past medical history of pulmonary tuberculosis:

1. First of all, to confirm or rule out reactivation tuberculosis.

2. The initial clinical manifestations of acute myeloid leukemia are unprovoked weakness for several months; increasing exertional dyspnea; anemia, leukopenia, neutropenia, ESR acceleration.

3. The primary methods to diagnose acute myeloid leukemia are clinical blood test with leukogram; biochemical blood tests to determine the levels of erythropoietin, ferritin and vitamin B12; bone marrow biopsy with aspirate examination (myelogram); cytochemical examination of bone marrow (myeloperoxidase); bone marrow immunophenotyping (expression of myeloid-associated antigens).

Prospects for further research. Further study of rare and complicated cases of tuberculosis combined with other diseases.

Conflicts of interest: authors have no conflict of interest to declare. Конфмікт інтересів: віАсутній. 
Надійшла Ао редакції / Received: 10.06.2020

Після Аоопрацювання / Revised: 17.06.2020

Прийнято Ао Аруку / Accepted: 26.06.2020

\section{Information about authors:}

Raznatovska O. M., MD, PhD, DSc, Professor, Head of Department of Phthisiology and Pulmonology, Zaporizhzhia State Medical University, Ukraine.

ORCID ID: 0000-0003-2252-9063

Shalmin 0. S., MD, PhD, DSc, Professor of the Department of Phthisiology and Pulmonology, Zaporizhzhia State Medical University, Ukraine.

Noreiko S. B., MD, PhD, DSc, Associate Professor, Professor of the Department of Phthisiology and Pulmonology, Bogomolets National Medical University, Kyiv, Ukraine.

\section{ORCID ID: 0000-0003-3139-5968}

\section{Відомості про авторів:}

Разнатовська О. М., А-р меА. наук, професор, зав. каф. фтизіатрії і пульмонології, Запорізький Аержавний меАичний університет, Україна.

Шальмін О. С., А-р меА. наук, професор каф. фтизіатрії і пульмонології, Запорізький Аержавний медичний університет, Україна.

Норейко С. Б., А-р меА. наук, Аоцент, професор каф. фтизіатрії та пульмонології, Національний медичний університет імені О. О. Богомольця, м. Київ, Україна.

\section{Сведения об авторах:}

Разнатовская Е. Н., А-р меА. наук, профессор, зав. каф. фтизиатрии и пульмонологии, Запорожский государственный медицинский университет, Украина. Шальмин А. С., А-р меА. наук, профессор каф. фтизиатрии и пульмонологии, Запорожский государственный меАицинский университет, Украина.

Норейко С. Б., А-р меА. наук, Аоцент, профессор каф. фтизиатрии и пульмонологии, Национальный медицинский университет имени А. А. Богомольца, г. Киев, Украина.

\section{References}

[1] Petrenko, V. I., Raznatovskaja, E. N., \& Radysh, A. V. (2014). Pobochnye reaktsii protivotuberkuleznykh preparatov [Adverse Reactions of TB Medicines]. OOO «VIT-A-POL», ChP «INPOL LTM». [in Russian].

[2] Arber, D. A., Orazi, A., Hasserjian, R., Thiele, J., Borowitz, M. J., Le Beau, M. M., Bloomfield, C. D., Cazzola, M., \& Vardiman, J. W. (2016). The 2016 revision to the World Health Organization classification of myeloid neoplasms and acute leukemia. Blood, 127(20), 2391-2405. https://doi.org/10.1182/blood-2016-03-643544

[3] Liu, C. J., Hong, Y. C., Teng, C. J., Hung, M. H., Hu, Y. W., Ku, F. C., Chen, Y. T., Chien, S. H., Yeh, C. M., Chen, T. J., Chiou, T. J., Gau, J. P., \& Tzeng, C. H. (2015). Risk and impact of tuberculosis in patients with chronic myeloid leukemia: a nationwide population-based study in Taiwan. International Journal of Cancer, 136(8), 1881-1887. https:// doi.org/10.1002/ijc.29201

[4] Jain, A., Prakash, G., Singh, C., Lad, D., Khadwal, A., Suri, V., Malhotra, P., Kumari, S., Varma, N., \& Varma, S. (2018). Analysis of Clinical Profile and Outcome of Tuberculosis in Patients with Acute Leukemia. Indian Journal of Hematology and Blood Transfusion, 34(3), 430-442. https:// doi.org/10.1007/s12288-017-0875-z

[5] Karachunskii, A. I., \& Yuldasheva, I. E. (2001). Tuberkulez u bol'nykh leikozom [Tuberculosis in patients with leukemia]. Problemy tuberkuleza, (8), 57-60. [in Russian].

[6] Nagayama, N., Shishido, Y., Masuda, K., Baba, M., Tamura, A., Nagai, H., Akagawa, S., Kawabe, Y., Machida, K., Kurashima, A., Komatsu, H., \& Yotsumoto, H. (2004). Leukopenia due to anti-tuberculous chemotherapy including rifampicin and isoniazid. Kekkaku, 79(5), 341-348. https://doi.org/10.11400/kekkaku1923.79.341

[7] Thomas, M., \& AlGherbawe, M. (2014). Acute Myeloid Leukemia Presenting with Pulmonary Tuberculosis. Case Reports in Infectious Diseases, 2014, Article 865909. https://doi.org/10.1155/2014/865909 